\title{
Implementation of Corporate Governance Standards for Company Growth and Development
}

\section{Sonja Tomaš Miskin"11,Branka Milošević Šnjegota12}

\begin{abstract}
Corporate Governance Standards (standards of corporation management) provide good grounds for effective implementation of key management principles, exercise of shareholders' rights and their equity stakes, equal treatment of shareholders, appropriate role of all other stakeholders in the manner of governance of a corporation, disclosure and transparency of information on company operation and appropriate role and responsibility of the boards established within the company. These standards are established on the basis of the Principles of Corporate Governance adopted by the Organization for Economic Cooperation and Development (OECD), and they are generally intended for use by developed corporations with a significant dispersion of ownership. Nevertheless, implementation of corporate governance standards was introduced also in the territory of Bosnia and Herzegovina, although in recent years, its capital markets (Sarajevo and Banja Luka) have been mainly trading in (short-term and long-term) debt securities issued by the Entity governments and, to a much lesser extent, in equity securities of incorporated state-owned enterprises. The aim of this paper is to show that implementation of corporate governance standards provides greater transparency in the operation of domestic listed companies, as well as a higher level of alignment of the domestic regulatory framework with the principles applied in the developed economies. This makes the domestic economic space more attractive for foreign investors, which implies that corporate governance standards directly support the growth and development of domestic companies and the economy as a whole. Basic scientific methods used to research the described issues include analysis methods (primarily the level of implementation of corporate governance standards in the country and its neighborhood), synthesis (in order to form conclusions about the effects of the attained corporate governance level) and comparison of solutions present in the practice of corporate governance in Bosnia and Herzegovina with the modalities present in its neighboring countries.
\end{abstract}

KEY WORDS: Corporate Governance Standards, Company, Transparency, Regulatory Framework

JEL: L53, D22, 016

UDC: 005.21:334.72.021

005.412

COBISS.SR-ID 238309388

\footnotetext{
${ }^{11}$ Faculty of Economics, University of Novi Sad, Novi Sad, Serbia, e-mail: sonjat984@gmail.com

${ }^{12}$ University of Business Studies Banja Luka,Banja Luka, Republic Srpska, e-mail:

bmilosevicsnjegota@yahoo.com
} 


\section{INTRODUCTION}

Introducing corporate governance standards in the countries of the former Yugoslavia has been gaining popularity in recent years as the state capital privatization process opened new possibilities to improve the system of operation in privatized companies. The term 'corporate governance' involves an entirety of relationships between a company's management, its management board and other boards established within, its shareholders and other stakeholders (OECD, 2015) and it is associated only with the companies not managed by their owners but rather by professional managers. Corporate governance standards, or standards of corporation management13, specify in detail the mechanisms of exercising and protecting the interests in mutual relations between various stakeholders in the operation of a corporation (joint stock company, company). Compliance with those standards should ensure improvement of the competitive ability of a company, achievement of more favorable conditions for investments activities, as well as a more efficient functioning of the financial market in general.

Corporate governance standards, established on the basis of the Principles of Corporate Governance adopted by the Organization for Economic Cooperation and Development (OECD) were last published in the Republic of Srpska in 2011 (Official Gazette of the Republic of Srpska, 2011), and in the Federation of $\mathrm{BiH}$ in 2010 (Official Gazette of the Federation of BiH, 2010). Their implementation should ensure:

- basis for effective implementation of corporate governance principles,

- rights of shareholders and key ownership functions,

- equal treatment of shareholders,

- appropriate role of all stakeholders in corporation governance,

- disclosure and transparency of information about the company, and

- appropriate role and responsibility of the boards established within the company.

Due to the fact that company's ability to generate operating profit in a long run can be designated as the main presumption for its growth and development, profitability can be deemed a common interest of the existing and potential shareholders, creditors, company management, the state and its institutions, as well as all other stakeholders. However, although all those parties have at least a minimum of common interests, each of them can have also their individual interests which need not be aligned with the interests of the company as a whole.

Generally, whenever a party has a discretionary possibility to make decisions which affect the interests of other stakeholders, potential conflicts of their interests (the so-called agency problems) arise due to a possibility of that party giving priority to their personal interests over those common. Within the corporate governance context, corporate governance standards may represent a significant factor of growth and development of a company, precisely because their implementation should ensure optimum exercise and protection of interests of all stakeholders in its operation.

\footnotetext{
${ }^{13}$ The term 'corporate governance standards' is used further in the text
} 


\section{IMPLEMENTATION OF CORPORATE GOVERNANCE STANDARDS IN BOSNIA} AND HERZEGOVINA AND NEIGHBORING COUNTRIES

The OECD Principles of Corporate Governance are established with a view to optimum organizational structure of a company, through which the objectives are set, the means of attaining those objectives are identified and the achieved results are monitored.

An effective implementation of corporate governance standards is possible only with the appropriate knowledge of and compliance with the legal and economic laws of operation in a corporate setting and by accepting the fact that such a form of business operation may affect significantly the achievement of general interests of the social community as a whole.

Corporate governance standards promote the principles of transparency, responsibility, professionalism and ethics in the behavior of all stakeholders (OECD, 2004, 2015). Finally, all those principles should increase the confidence of the existing and potential investors and encourage company growth and development. Accordingly, the corporate governance framework should promote an open and efficient market, be based on the principles of the rule of law and ensure a clear division of authority and responsibility between various supervisory and regulatory bodies within or outside the company.

Conflict of interest between the shareholders and managers, as well as conflict of interest between the majority and minority shareholders, on the one hand, and biased financial reporting, distorting capital market integrity and inexistence of regulations to prevent abuses, on the other hand, have brought about the establishment of a system, structure, mechanisms and policies which include the processes and rules explaining the relations between all participants (stakeholders - author's note) in a company, so as to enable them to fulfil their rights and obligations in a correct and proportional manner (Đorđević, 2012).

The corporate governance framework should protect and facilitate the exercise of rights of all shareholders and other stakeholders specified by law or appropriate contracts and agreements and encourage active cooperation between the company and the stakeholders in achieving their common interests. In order to make this possible, one of the objectives of corporate governance standards concerns timely and accurate disclosure of all material information about company operation, including information about its financial standing, performance, governance etc., as well as providing efficient supervision of the management and responsibility of the board towards the company and its shareholders.

Without an efficient corporate governance system in a country, it is not possible to ensure the interest of investors, in particular those foreign, to invest in the economy of that country. Therefore, the final reach of corporate governance should be way beyond the interests of individual companies in establishing such a system, because the attained level of implementation of corporate governance standards largely shapes the volume and quality of investments which in turn shape the economic development of the country. Evidently, in addition to the regulations directly related to corporate governance standards, also the overall legal and economic system of a country should be focused on attaining the objectives on which the standards are founded.

The structure of corporate governance standards in force in Bosnia and Herzegovina consists of the following:

i. rights of shareholders

- right to govern a corporation

- $\quad$ right to timely and regular obtaining of relevant information about the company

- $\quad$ preemptive right to acquire new shares 
- $\quad$ right to a share in profit of the corporation

- right to dispose freely of shares

- right to a secure and fast ownership registration,

- right of shareholders to elect and remove the members of the management/supervisory board and to be elected to the management/supervisory board,

- $\quad$ right to disagree and have the company redeem the shares,

- right to file action,

- $\quad$ right to a share in liquidation surplus

ii. equal treatment of all shareholders

iii. role of other stakeholders

iv. disclosure and transparency of information

v. role and responsibility of the board

vi. role and responsibility of company management

vii. role and responsibility of company's management/supervisory board

viii. conflict of interest in company's bodies

ix. independence of members of the management/supervisory board

$\mathrm{x}$. remunerations of members of the management/supervisory board and management

xi. internal audit and audit board

xii. independent auditor

xiii. internal control and

xiv. relationships with other stakeholders.

Corporate governance standards primarily support the process of equal, efficient and transparent exercise of the fundamental rights of shareholders: right to govern a company, right to a share in the distribution of net profit and right to a share in liquidation assets. However, in addition to protecting shareholders' interests, corporate governance standards are aimed at ensuring compliance with and exercise of legal rights of all other stakeholders in company operation. Therefore, the system of company governance should be founded on active cooperation of governing bodies with all stakeholders, with a view to creating general wellbeing, preserving the existing workplaces and opening the new, and maintaining financial stability of the company and thereby also of the social community as a whole in a long run.

The efficiency and effectiveness of corporate governance can be achieved through various mechanisms, which can be divided most generally into internal and external. The most important internal mechanisms of corporate governance are: management monitoring by the management and supervisory board, appropriate systems of incentives for mangers, internal audit and control by large institutional investors (Đorđević, 2012).

In many countries, a large portion of responsibility for disclosing company information is borne by stock exchanges, securities commissions and similar institutions. Indeed, stock exchanges are in a position to contribute to the improvement of transparency by establishing codes, standards and various systems for assessing transparency level (Todorović et al, 2013).

In transition countries, companies have been mostly privatized and corporations established. Many corporation members are not aware of their rights and obligations or of their role of a manager, management member or shareholder. Many corporations are not in a position to provide a timely and useful information to investors, which constitutes a risk. Only a complete, true information leads to a transparency which enables the investors and shareholders to continually evaluate corporations and adjust the evaluation to corporation shares (Kukobat et al, 2016).

We are familiar with the most frequent manner of privatization in our region, so a majority owner who is not interested in issuing shares cannot be expected to be particularly interested in improving transparency (Todorović et al, 2013). 
The level of transparency of information regarding company operation is in a key causeand-effect relationship with the (in)efficient implementation of corporate governance standards. Unwillingness of the management to make the information regarding company operation available to shareholders and other interested public impairs directly the confidence in that company and the level of attainment of objectives which should be achieved through the implementation of corporate governance standards, and vice versa, inefficient implementation of those standards leads to a particular isolation of the company in the economic, social and every other sense. If such an occurrence can be deemed typical of a business community, it is easy to conclude that the damage it causes is direct, immeasurable and affecting not only individual companies and the business community, but also the society as a whole.

Corporate governance standards represent good grounds for the preparation of the socalled scorecard analysis (tool) to evaluate good practices of corporate governance. So, for example, the structure of a scorecard promoted by the Banja Luka Stock Exchange (www.blberza.com) includes the criteria which cover the standards of corporation management and a relevant set of questions for a total of seven fields as follows: commitment to the principles of corporate governance, rights of shareholders, equal treatment of shareholders, role of stakeholders in corporation governance, disclosure and transparency of information, role and responsibility of the board, and audit and internal control system.

Table 1: Scorecard analysis of the Banja Luka Stock Exchange - disclosure and transparency of information

\begin{tabular}{|c|c|c|c|c|c|}
\hline & \multicolumn{3}{|c|}{ Answers (1) } & \multirow[t]{2}{*}{$\begin{array}{c}\text { Standard } \\
\text { weighting (2) }\end{array}$} & \multirow[t]{2}{*}{$\begin{array}{c}\text { Score }(3)= \\
(1) \times(2)\end{array}$} \\
\hline & 1 & 0.5 & 0 & & \\
\hline & yes & partially & no & & \\
\hline $\begin{array}{l}\text { V 1. Does the company duly } \\
\text { disclose its financial statements and } \\
\text { external audit reports? }\end{array}$ & & & & $20 \%$ & $0.00 \%$ \\
\hline $\begin{array}{l}\text { V 2. Does the company publish } \\
\text { details of related party transactions, } \\
\text { in particular of those with related } \\
\text { legal entities in the form of } \\
\text { consolidated financial statements } \\
\text { prepared in accordance with the } \\
\text { accounting standards? }\end{array}$ & & & & $10 \%$ & $0.00 \%$ \\
\hline $\begin{array}{l}\text { V 3. Does the company disclose } \\
\text { information of intangible nature } \\
\text { (development plans, company } \\
\text { objectives, etc.) regarding } \\
\text { company's business? }\end{array}$ & & & & $10 \%$ & $0.00 \%$ \\
\hline $\begin{array}{l}\text { V } 4 \text {. Does the company disclose } \\
\text { information on relevant events, major } \\
\text { transactions and relevant material } \\
\text { information on company operation in } \\
\text { a transparent and timely manner? }\end{array}$ & & & & $10 \%$ & $0.00 \%$ \\
\hline $\begin{array}{l}\text { V 5. Does the company disclose } \\
\text { information on shareholders' shares } \\
\text { of over } 10 \% \text { in other companies along } \\
\text { with the name and seat of the } \\
\text { respective company and percentage of } \\
\text { the share? }\end{array}$ & & & & $15 \%$ & $0.00 \%$ \\
\hline
\end{tabular}




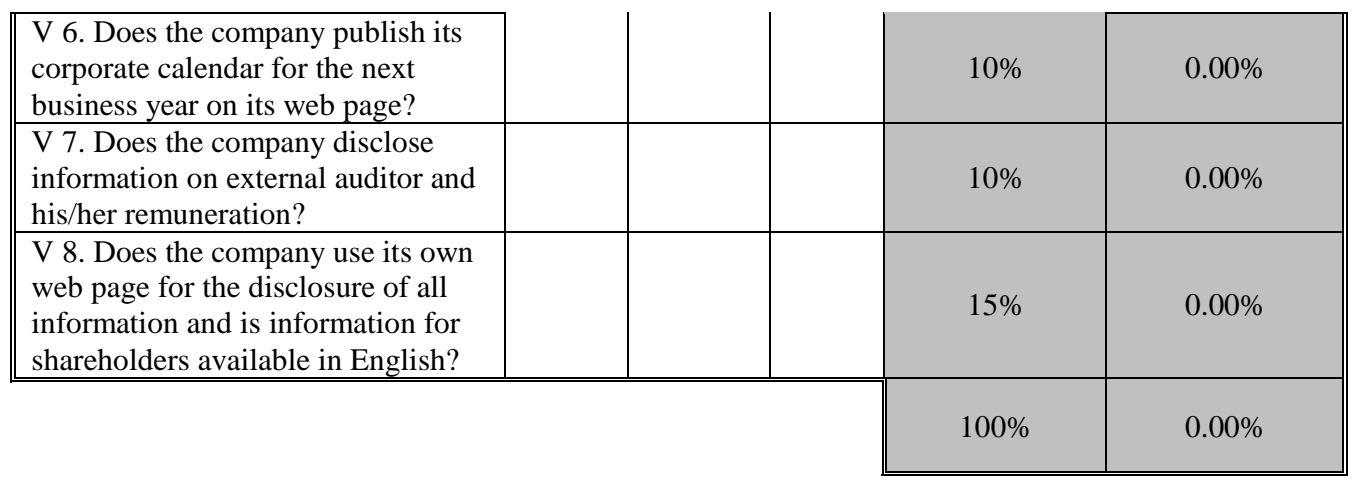

\section{Source: www.blberza.com}

According to this methodology, the shares in the overall score are as follows: commitment to the principles of corporate governance $10 \%$, rights of shareholders $20 \%$, equal treatment of shareholders $10 \%$, role of stakeholders in corporation governance $10 \%$, role and responsibility of the board $20 \%$, and audit and internal control system $10 \%$. The remaining $20 \%$ account for the disclosure and transparency of information.

A similar basic approach when preparing a scorecard analysis is applied also at the Belgrade Stock Exchange (www.belex.rs). The structure of the scorecard consists of the main criteria which reflect the principles and recommendations of best practice of corporate governance incorporated in the national legislation and codes of corporate governance in Serbia. The criteria are systematized by field, with a relevant set of questions for each field. The analysis covers six fields: commitment to the corporate governance and social responsibility principles $(10 \%)$, shareholders and general meeting of shareholders $(15 \%)$, management board $(20 \%)$, company's executive bodies and secretary $(15 \%)$, supervision, control and external audit operations (20\%), and transparency and disclosure (20\%).

Table 2: Scorecard analysis of the Belgrade Stock Exchange - transparency and disclosure

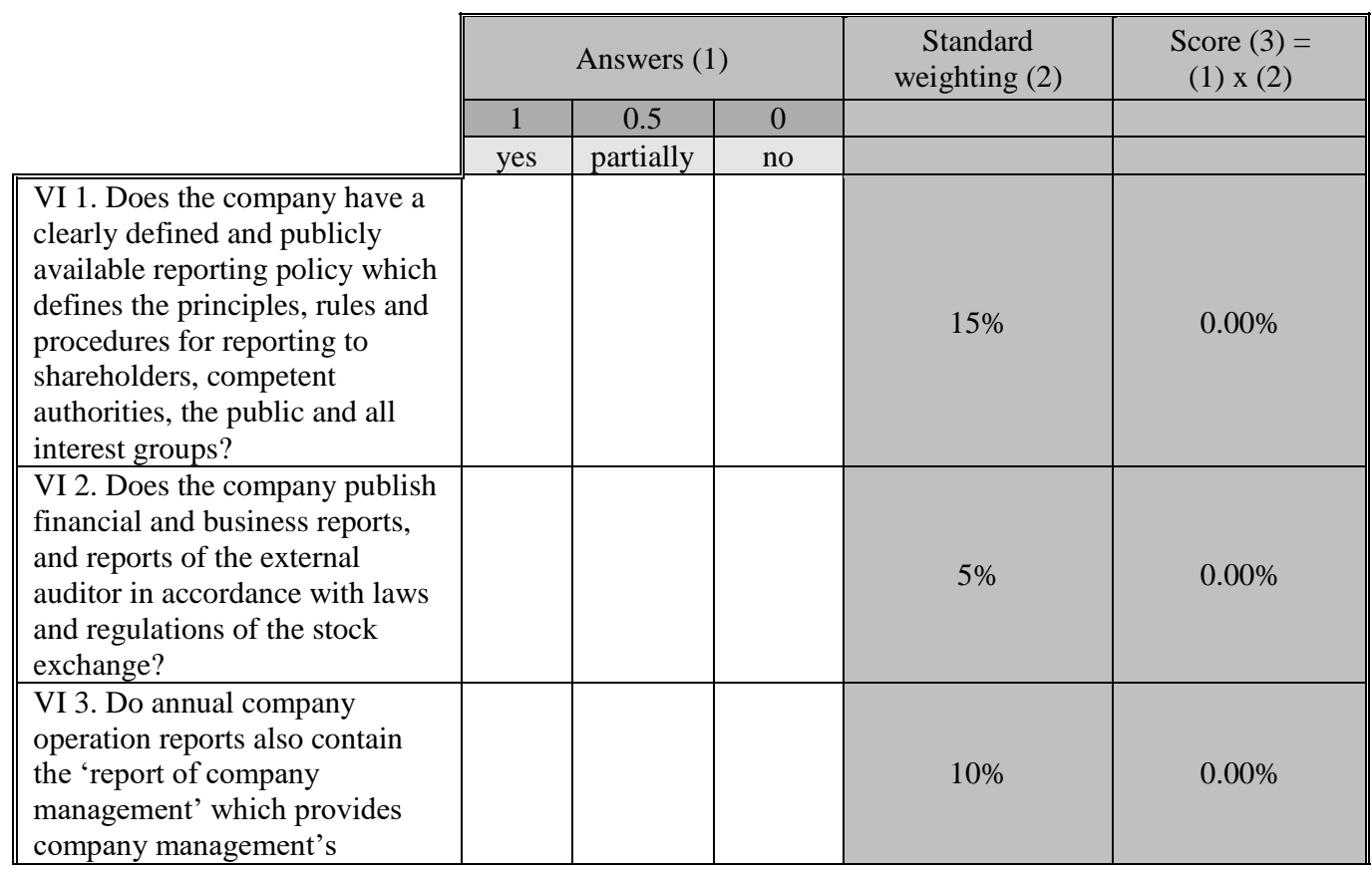




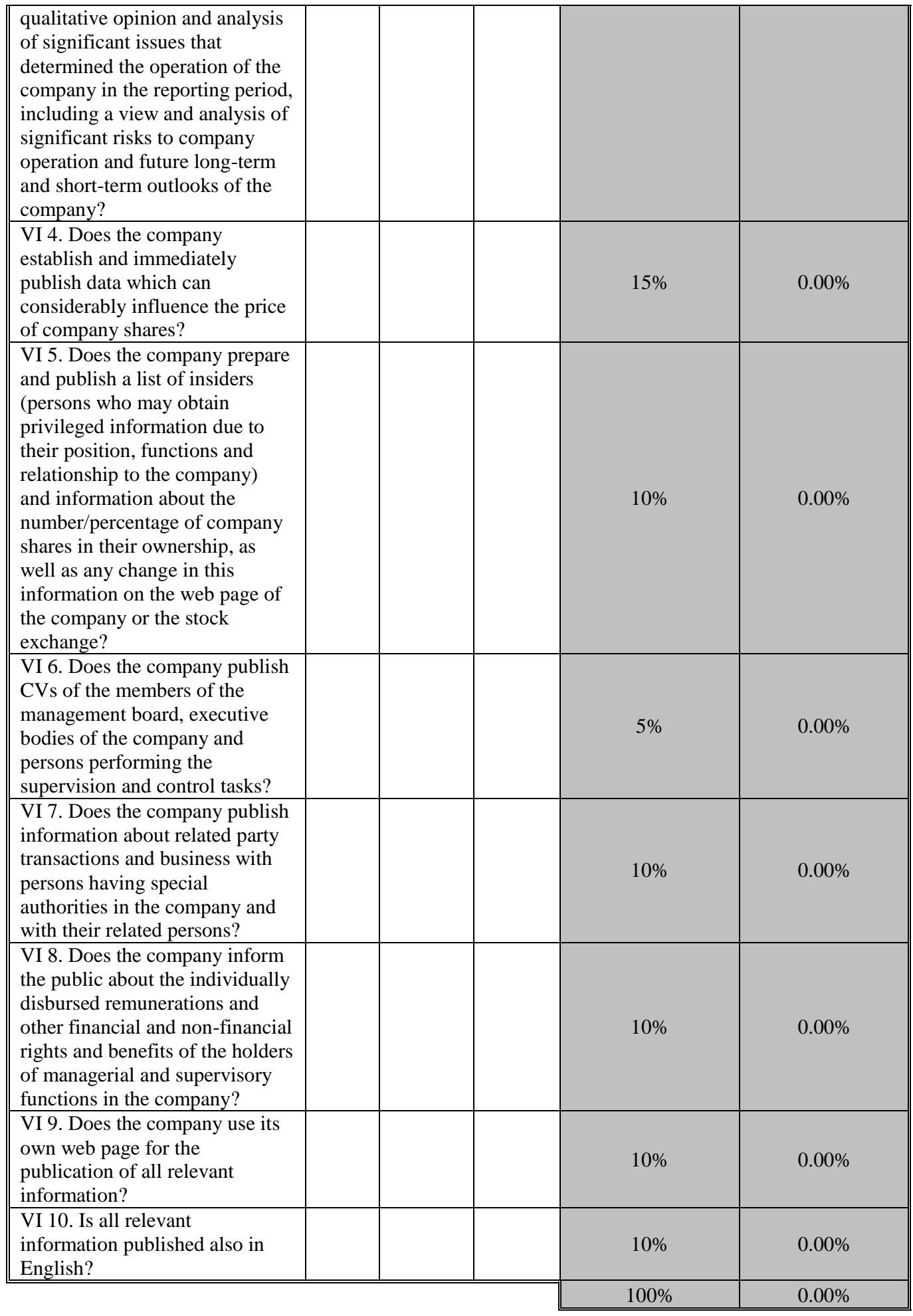


The Croatian Code of Corporate Governance (www.zse.hr) in its structure also represents a standard form of the OECD standards and guidelines of corporate governance. The Corporate Governance Code for Companies Listed on the Macedonian Stock Exchange was adopted in 2006 (www.mse.mk) and essentially does not differ significantly from the documents of similar type and purpose applied in the neighboring countries.

Table 3: Scorecard analysis of the Macedonian Stock Exchange - transparency and disclosure $20 \%$ relative weighting in the overall analysis)

\begin{tabular}{|c|c|c|c|c|c|}
\hline & \multicolumn{3}{|c|}{ Answers (1) } & \multirow[t]{2}{*}{$\begin{array}{c}\text { Standard } \\
\text { weighting (2) }\end{array}$} & \multirow[t]{2}{*}{$\begin{array}{l}\text { Score (3) }= \\
\text { (1) } \mathrm{x}(2)\end{array}$} \\
\hline & 1 & 0.5 & 0 & & \\
\hline & yes & partially & no & & \\
\hline $\begin{array}{l}\text { IV 1. The company discloses } \\
\text { immediately all material information } \\
\text { to the Macedonian Stock Exchange } \\
\text { and on its web page }\end{array}$ & & & & $25 \%$ & $0.00 \%$ \\
\hline $\begin{array}{l}\text { IV } 2 \text {. The company discloses in a } \\
\text { timely manner and in full all } \\
\text { material information related to: a) } \\
\text { overall company objectives and } \\
\text { tasks for the coming period; b) } \\
\text { certified auditors; c) material risk } \\
\text { factors; d) related party } \\
\text { transactions; e) major } \\
\text { transactions; f) changes in the } \\
\text { share capital and in the results of } \\
\text { operation in the corresponding } \\
\text { reporting period }\end{array}$ & & & & $35 \%$ & $0.00 \%$ \\
\hline $\begin{array}{l}\text { IV 3. For each supervisory board } \\
\text { member, the annual company report } \\
\text { contains information about the sex, } \\
\text { age, profession, fees and salaries and } \\
\text { other rights arising from their } \\
\text { engagement, their citizenship, date of } \\
\text { initial appointment to the function } \\
\text { and duration of their current term, as } \\
\text { well as information about their } \\
\text { potential membership in the board of } \\
\text { directors/ supervisory board in other } \\
\text { legal entities which are relevant for } \\
\text { the performance of their function of a } \\
\text { supervisory board member }\end{array}$ & & & & $15 \%$ & $0.00 \%$ \\
\hline $\begin{array}{l}\text { IV 4. The annual report contains } \\
\text { information on the remuneration } \\
\text { of each existing supervisory board } \\
\text { member }\end{array}$ & & & & $15 \%$ & $0.00 \%$ \\
\hline $\begin{array}{l}\text { IV 5. The company has adopted an } \\
\text { internal act which ensures a regular, } \\
\text { timely and equitable dissemination of } \\
\text { information to all shareholders and } \\
\text { the public at large }\end{array}$ & & & & $10 \%$ & $0.00 \%$ \\
\hline & & & & $100 \%$ & $0.00 \%$ \\
\hline
\end{tabular}

Source: www.mse.mk 
The board of directors of the Montenegro Stock Exchange (www.montenegroberza.com) adopted the Montenegrin Code of Corporate Governance in 2009 and the scorecard in 2011. Also here, the questions for evaluation of the level of harmonization with corporate governance standards are systematized in six fields: commitment to the corporate governance and social responsibility principles (10\%), shareholders and general meeting of shareholders (20\%), board of directors $(25 \%)$, company's executive bodies and secretary $(10 \%)$, supervision, control and independent audit operations (10\%) and operation transparency and disclosure (25\%).

In this case, the weighting relevant for operation transparency and disclosure is assigned a relatively higher importance, and its structure is as follows:

Table 4: Scorecard analysis of the Montenegro Stock Exchange - transparency and disclosure

\begin{tabular}{||c|c||}
\hline \multicolumn{1}{|c|}{ Criteria within the field of operation transparency and disclosure } & Weighting \\
\hline $\begin{array}{l}\text { VI 1. Does the company have a clearly defined and publicly available } \\
\text { reporting policy which provides for equal dissemination of information to } \\
\text { shareholders on all issues? }\end{array}$ & $15 \%$ \\
\hline $\begin{array}{l}\text { VI 2. Does the company publish its financial and business reports, and } \\
\text { reports of the external auditor in accordance with laws and rules of the } \\
\text { stock exchange? }\end{array}$ & $10 \%$ \\
\hline $\begin{array}{l}\text { VI 3. Does the company publish information about cross shareholding and } \\
\text { changes in that matter on its web page? }\end{array}$ & $10 \%$ \\
\hline $\begin{array}{l}\text { VI 4. Does the company provide and immediately publish data which can } \\
\text { influence the price of company shares and risk factors, and is this } \\
\text { information published on the web page of the company or the stock } \\
\text { exchange? }\end{array}$ & $15 \%$ \\
\hline $\begin{array}{l}\text { VI 5. Does the company publish annual management report which includes } \\
\text { significant issues of company operation, development plans of the } \\
\text { company and main characteristics of corporate governance of the company } \\
\text { during the reporting period? }\end{array}$ & $10 \%$ \\
\hline $\begin{array}{l}\text { VI 6. Does the company publish CVs of the members of the board of } \\
\text { directors, executive director and persons performing the supervision and } \\
\text { control tasks? }\end{array}$ & $5 \%$ \\
\hline $\begin{array}{l}\text { VI 7. Does the company publish information about related party } \\
\text { transactions and business with persons having special authorities in the } \\
\text { company and with their related persons? }\end{array}$ & $10 \%$ \\
\hline $\begin{array}{l}\text { VI 8. Does the company publish information about the number/percentage } \\
\text { of company shares owned by the members of the board of directors of the } \\
\text { company, executive director and secretary of the company, as well as any } \\
\text { change in this information on the web page of the company or the stock } \\
\text { exchange? }\end{array}$ & $10 \%$ \\
\hline $\begin{array}{l}\text { VI 9. Does the company publish the policy of rewarding the board of } \\
\text { directors and executive director? }\end{array}$ & $5 \%$ \\
\hline $\begin{array}{l}\text { VI 10. Does the company use its own web page for the publication of all } \\
\text { relevant information in both Montenegrin and English? }\end{array}$ & $10 \%$ \\
\hline \multicolumn{1}{|c||}{ TOTAL } \\
\hline
\end{tabular}

Source: www.montenegroberza.com 
The above analysis shows that the countries emerged in the territory of the former Yugoslavia started assigning particular importance to the standards or codes of corporate governance in the second half or the end of the first decade of the $21^{\text {st }}$ century. Key activities on establishing and promoting those standards were undertaken by stock exchanges - regulated capital markets and their regulators, primarily securities commissions. This can be explained by the fact that this was the time of a particularly prominent endeavor by the relevant institutions to give an entirely new dimension to one of the very important segments of the transition process the development of corporate governance in the newly established corporations, former stateowned enterprises that had undergone the privatization and corporatization process to be listed on the domestic capital markets, and thereby to provide also a strong incentive to the development of the domestic capital market which had by then already played its primary role in the newly emerged state unions.

\section{AGENCY PROBLEMS AS AN OBSTACLE TO EFFICIENT CORPORATE GOVERNANCE}

The term 'agency problem' originated as an attempt to explain numerous situations in which many persons take part in various ways in a specific joint venture, where the interests of at least one of them potentially diverge from the interests of other participants, and that one person has a possibility, based on the authority received from the others, to make discretionary decisions which affect the success of the joint venture.

Agency problems can exist in any situation in which two or more parties are led to act together to achieve a certain common interest, where it is impossible to avoid potential disharmony between the individual interests of the participants entitled to make decisions and the interests of other stakeholders.

An effective system of corporate governance facilitates the process of decision-making and delegating authority and responsibility within an organization. The biggest problem caused by the separation of governance from ownership arises from the fact that the interests of managers are not fully aligned with those of the owners, and that the owners do not have unlimited possibilities of control over the work of the managers who manage their capital. On the other hand, managers have much better and more comprehensive information which enable their deviant behavior, resulting in a principal (manager) - agent (owner) problem, or agency problem as it is known in literature (Lukić, 2014).

In the operation of corporations it is possible to define three main agency problems between the following: management - shareholders, majority shareholder - non-controlling shareholders (minority shareholders) and company - other stakeholders in company operation (creditors etc.).

The first problem is characteristic of companies with a dispersed ownership structure, i.e. participation of a relatively large number of small shareholders in the ownership of the company, while the second concerns the existence of a controlling shareholder and a conflict between his/her interests and those of non-controlling shareholders. Unlike those two, the third agency problem is unrelated to ownership structure and it is present in almost all corporations.

By transfer of the authority for company governance to professionals, competent managers are enabled to manage the company efficiently, regardless of the wealth at their disposal, while the interested investors are given the possibility to invest efficiently in the capital market, regardless of their managerial skills. However, higher ownership dispersion and higher intensity of separation of ownership from managerial rights increase the risk of a potential conflict of interest between the management and shareholders, where the management cares more about its own interests, regardless of the degree to which those diverge from the interests of the owners. 
In companies with a dispersed ownership structure, the shareholders objectively cannot fully supervise the work of the management and they have no possibility to become directly involved in the process of business decision-making. For that reason, the managers have a rather large independence and autonomy in their daily work and implementation of business policies of the company. The first agency problem will arise every time the management aims its decisions at achieving personal interests, disregarding the interests of the company and its shareholders. Numerous examples show that such a strategy does not support company growth and development, and that it may easily lead to its breakdown and immense consequences for all stakeholders.

The countries where shareholding is insufficiently developed are dominantly characterized by the existence of a single or potentially a group of shareholders who exercise control over the company. Such circumstances produce not only the absence of separation but, on the contrary, the merging of company ownership and management. Since the controlling shareholders govern the company directly or indirectly, the first agency problem does not arise frequently, because the management can be naturally expected to work primarily in the interest of the controlling shareholder. Instead, the main problem of such corporate governance is precisely the managers not carrying out their activities in the interest of the company, but in the interest of the majority shareholder, where interests of minority shareholders are usually insufficiently protected.

The third agency problem is manifested as a conflict of interest between the corporation (shareholders and management) and other stakeholders in its operation (potential investors, banks and other financial organizations, the state, employees, suppliers, consumers etc.).

Relevant legal regulations concerning company law and corporate governance practice usually do not provide appropriate protection of the interests of other holders of risks of company operation. In itself, that does not necessarily represent a problem if their individual or general interests are protected or can be protected based on other regulations (regulations governing employment rights, rights arising from obligations, accounting and auditing, consumer protection, enforcement procedure, bankruptcy proceedings, environmental protection, etc.).

Unresolved agency problems at a micro level can cause inefficient company governance, its unprofitable operation, illiquidity and insolvency, neglect of the interests of individual stakeholders etc. At a macro level, they can create lack of confidence with the public in securities market and shareholding in general, various stock exchange problems including a possibility of stock exchange crash, unemployment growth and numerous other consequences unfavorable for the entire society. For that reason, the main purpose of development of good practice of corporate governance should be sought in resolving or at least reducing agency problems.

In the countries with transition economies, shareholding cannot objectively be developed to a sufficient extent. As a consequence of insufficiently developed shareholding, undeveloped financial market, absence of long-term strategy of growth and development of corporations, usual preference for short-term economic objectives of individual stakeholders, etc., the second and the third agency problem become hardly surmountable obstacles to the development of corporate governance, particularly under the conditions of economic and financial crisis.

One of the main objectives of corporate governance standards concerns precisely the need to establish clear rules whose implementation should ensure that company management works primarily for the benefit of the company, i.e. for the benefit of all investors and creditors, not only for their own benefit or that of majority shareholders. However, an insufficiently conscientious management holding the decision-making power can hardly be expected, without a legal coercion, to respect the rules which are essentially not binding but only provide recommendations and suggestions. 
According to the corporate governance standards in force, a company should ensure timely disclosure and transparency of information about all material issues concerning the company, including its financial standing, operation, ownership and company governance. Publication of financial statements and other information about the company should enable its appraisal in terms of legal status, financial position, business opportunities and rights concerning securities. The statements must include understandable comments and analysis of operation prepared by company management.

A subject of particularly detailed reporting should be transactions with related parties, especially with those whose financial statements should be included in the consolidated financial statements of the company. In its financial statements, the company should also give a statement about compliance with corporate governance principles and standards.

Establishing special rules of publishing information on related legal entities operating within business groups can also be considered as a way to resolve or alleviate the third agency problem. Business groups can have a negative impact on the rights of creditors in various ways. Primarily, because the business between group members is naturally connected with the risk that all benefits of that business would be transferred to the controlling member (parent legal entity) by transfer pricing, and that all or most business risks would be borne by the controlled (subsidiary) legal entities.

Implementation of corporate governance standards, in addition to other mechanisms, should enable early detection of the causes of crisis and appropriate response by the management before the requirements are fulfilled for instituting bankruptcy proceedings. And if those proceedings turn out to be unavoidable, it should at least ensure that bankruptcy proceedings start at the earliest possible convenience, before the company is deprived of any chance of survival.

\section{CONCLUSION}

Corporate governance standards primarily support the process of equal, efficient and transparent exercise of the fundamental rights of shareholders: right to govern a company, right to a share in the distribution of net profit and right to a share in liquidation assets. However, in addition to protecting shareholders' interests, implementation of corporate governance standards should also ensure compliance with and exercise of legal rights of all other stakeholders in company operation. Therefore, the system of company governance should be founded on active cooperation of governing bodies with all stakeholders with a view to creating general wellbeing, preserving the existing workplaces and opening the new, and maintaining financial stability of the company and thereby also of the social community as a whole in a long run.

The level of transparency of information regarding company operation is in a key causeand-effect relationship with the (in)efficient implementation of corporate governance standards. Unwillingness of the management to make the information regarding company operation available to shareholders and other interested public impairs directly the confidence in that company and the level of attainment of objectives which should be achieved through the implementation of corporate governance standards, and vice versa, inefficient implementation of those standards leads to a particular isolation of the company in the economic, social and every other sense. If such an occurrence can be deemed typical of a business community, it is easy to conclude that the damage it causes is direct, immeasurable and affecting not only individual companies and the business community, but also the society as a whole.

Based on the analysis of the existing legal solutions for mandatory preparation and presentation of appropriate information regarding operation of corporations, it can be concluded that relevant legal regulations mainly encompass what is necessary for the development of good practice of corporate governance, and thereby for growth and development of domestic companies and development of shareholding in general at our territory. 
However, bearing in mind the degree of economic development in $\mathrm{BiH}$ and neighboring countries, objectively inadequate level of development of corporate governance and shareholding in general, inadequate level of efficiency and effectiveness of financial markets, in particular of capital markets, the fact that the term 'corporate governance' is mainly associated with the 'companies' which emerged from the former state-owned enterprises and other entities normally still majority-owned by the state and its institutions (funds etc.), the examples of good practice of corporate governance, although relatively rare, mostly include the successfully privatized state entities (banks, enterprises, etc.) or scarce corporations initially established in the form of a classic company. Apart from the financial sector (banks, investment funds, etc.), the examples of good practice of corporate governance may include Telekom Srpske a.d. Banja Luka in the Republic of Srpska, NIS a.d. Novi Sad in Serbia, INA d.d. Zagreb in Croatia, Makpetrol a.d. Skopje in Macedonia and so on.

From the above examples it is easily concluded that under the domestic economic conditions, good practices of corporate governance are mainly associated with companies of a large economic strength which, by their very nature, operate in profitable and attractive branches of economy such as petroleum industry, telecommunications, etc.

\section{REFERENCES}

[1]Đorđević, S. (2012). Značaj i uloga mehanizama korporativnog upravljanja u podizanju nivoa efikasnosti menadžmenta. Visoka poslovna škola strukovnih studija Novi Sad, Škola biznisa, br. 1/2012, www.vps.ns.ac.rs,

[2]Kukobat, L., Tešanović, S., Kukić, S. (2016). Korporativno upravljanje u Srbiji: problem malih akcionara. Univerzitet Singidunum Beograd, Finiz 2016, p. 111-116,

[3]Lukić, J. (2014). Motivacione strategije rešavanja agencijskog problema. Univerzitet u Beogradu, Ekonomski fakultet, Finiz 2014, p. 91-93,

[4]OECD Principles of Corporate Governance, 2004., (2015). http://www.oecd.org,

[5]Pravilnik o upravljanju dioničarskim društvima. Službene novine Federacije BiH, broj 19/10,

[6]Standardi korporativnog upravljanja. Službeni glasnik Republike Srpske, broj 117/11,

[7]Todorović, Z., Bunić, S., Todorović, I. (2013). Transparentnost u korporativnom upravljanju. Ekonomski fakultet Univerziteta u Banjoj Luci, Acta Economica br. 19, p. 9-39;

[8]www.belex.rs, Belgrade Stock Exchange

[9]www.blberza.com, Banja Luka Stock Exchange

[10]www.montenegroberza.com, Montenegro Stock Exchange

[11]www.mse.mk, Macedonian Stock Exchange

[12]www.zse.hr, Zagreb Stock Exchange

\section{Article history:}

- $\quad$ Received 15 March 2017

- Accepted 20 May 2017 